\title{
Bacterial community structure and diversity along the halocline of Tyro deep-sea hypersaline anoxic basin
}

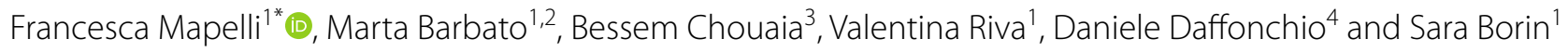

\begin{abstract}
Purpose: Tyro is a deep hypersaline anoxic basin (DHAB) located at the seafloor of the Eastern Mediterranean sea. Tyro hosts a stratified eukaryotic microbiome moving from seawater to the brine, but no reports are available on its prokaryotic community. We provide the first snapshot of the bacterial community structure in Tyro brine, seawaterbrine interface, and the overlaying deep seawater.

Methods: In this study, we combined the use of molecular analyses, i.e., DNA fingerprinting and 165 rRNA pyrosequencing for the description of the bacterial community structure and taxonomy. PiCRUST2 was used to infer information on the prokaryotes functional diversity. A culture-dependent approach was applied to enrich bacteria of interest for marine biotechnology.

Results: Bacterial communities sharply clustered moving from the seawater to the Tyro brine, in agreement with the abrupt increase of salinity values. Moreover, specific taxonomic groups inhabited the seawater-brine interface compared to the overlaying seawater and their identification revealed converging taxonomy with other DHABs in the Eastern Mediterranean sea. Functional traits inferred from the prokaryote taxonomy in the upper interface and the overlaying seawater indicated metabolic pathways for the synthesis of osmoprotectants, likely involved in bacterial adaptation to the steep increasing salinity. Metabolic traits related to methane and methylated compounds and to hydrocarbon degradation were also revealed in the upper interface of Tyro. The overall capability of the Tyro microbiome for hydrocarbon metabolism was confirmed by the isolation of hydrocarbonoclastic bacteria in the sediments.

Conclusions: Our results suggest that Tyro seawater-brine interface hosts a specific microbiome adapted to the polyextreme condition typical of DHABs with potential metabolic features that could be further explored for the characterization of the metabolic network connecting the brine with the deep seawater through the chemocline. Moreover, Tyro could be a reservoir of culturable microbes endowed with functionalities of interest for biotechnological applications like hydrocarbon bioremediation.
\end{abstract}

Keywords: Halocline, Eastern Mediterranean, Deep sea, Hydrocarbonoclastic bacteria, Extremophiles, Microbiome, PiCRUSt2

*Correspondence: francesca.mapelli@unimi.it

1 Department of Food, Environmental and Nutritional Sciences (DeFENS), University of Milan, Via Celoria 2, 20133 Milan, Italy

Full list of author information is available at the end of the article

\begin{abstract}
Introduction
Deep hypersaline anoxic basins (DHABs) are extreme habitats located on the ocean floor in several areas of the world (Mapelli et al. 2017a). DHABs likely originated from the dissolution of evaporites due to tectonic events, and all share some common features (Merlino et al. 2018). In particular, the different density of the brine and the
\end{abstract} original author(s) and the source, provide a link to the Creative Commons licence, and indicate if changes were made. The images or other third party material in this article are included in the article's Creative Commons licence, unless indicated otherwise in a credit line to the material. If material is not included in the article's Creative Commons licence and your intended use is not permitted by statutory regulation or exceeds the permitted use, you will need to obtain permission directly from the copyright holder. To view a copy of this licence, visit http://creativecommons.org/licenses/by/4.0/. 
overlying seawater prevents these two layers from mixing, implying the presence of a seawater-brine interface with a sharp pycnocline where steep gradients of salinity, oxygen, and nutrients occur (Daffonchio et al. 2006). Given the polyextreme conditions (i.e., high hydrostatic pressure, anoxia, absence of light) to which microbial life is subjected, DHAB interfaces represent natural laboratories to observe the adaptation of microbes across changing conditions, especially along salinity gradients, i.e., haloclines (Borin et al. 2013).

Nine DHABs have been discovered in the Eastern Mediterranean sea to date, and, in the last two decades, these extreme ecosystems have been studied for their unique microbiology (Borin et al. 2009; Daffonchio et al. 2006; La Cono et al. 2019, 2011; Van Der Wielen et al. 2005; Yakimov et al. 2015, Yakimov et al. 2013). Tyro basin was discovered during the eighties of the last century, and geochemical studies, dissecting its concentration of ions and salts, demonstrated the occurrence of a thalassohaline brine (De Lange et al. 1990). Differently from other Eastern Mediterranean DHABs, the microbial community occurring at the Tyro basin was investigated only focusing on eukaryotes (Filker et al. 2013; Stock et al. 2013). Protists, mainly represented by alveolates, stramenopiles, and kinetoplastids, inhabit the Eastern Mediterranean DHABs, including Tyro, where flourishing prokaryote networks support their growth (Filker et al. 2013). Molecular analyses based on fingerprinting or high-throughput sequencing methods were used to describe the structure of the overall protist community of the Urania, Thetis, Discovery, Medee, and Tyro basins (Filker et al. 2013; Stock et al. 2013) demonstrating that specific populations colonized the diverse environmental niches represented by brines and seawater-brine interfaces. Such studies revealed that Tyro interface, in terms of eukaryotic community composition, is more similar to the brine of the other DHABs (i.e., Thetis, Medee, Urania) rather than their interfaces.

Although a novel methanogenic archaeal species, highly adapted to the specific physicochemical conditions, was recently isolated from Tyro (L'Haridon et al. 2020), no reports are available on the diversity of prokaryotic communities inhabiting this basin. We hypothesized that bacteria populations are subjected to distribution patterns like those observed for protists; thus, in this study, we investigated the overall structure of the bacterial communities dwelling in the brine, seawater-brine interface, and the deepest layer of the water column overlaying the Tyro basin.

As we previously demonstrated, even mild hydrostatic pressure may deeply influence the transcriptomic profiles of marine bacteria and the composition of microbial communities involved in specific ecological services, such as hydrocarbon degradation (Barbato et al. 2016b; Barbato and Scoma 2020). Hydrocarbonoclastic bacteria isolated from DHABs have been recognized as valuable resources exploitable for bioremediation of hypersaline marine ecosystems (Varrella et al. 2020). Being subjected to high hydrostatic pressure, Tyro basin sediments were used to setup enrichment cultures because they could host hydrocarbonoclastic bacteria adapted to the specific conditions occurring in the deep sea, possibly representing a source of competitive microbial resources to combat oil spills at high depth.

\section{Materials and methods}

\section{Sampling and onboard measurements}

Halocline fractions were collected with previously described procedures (Daffonchio et al. 2006) during the Ulixes U11-1 oceanographic cruise, in September 2011, from the Tyro DHAB (33 $52.698 \mathrm{~N}, 26^{\circ} 02.336$ E). Niskin bottles, housed on a cable-connected rosette sampler under the control of Conductivity-TemperatureDepth sensors, were closed in the seawater-brine interface (identified by a large increase in conductivity), in the brine (3521 meter b.s.l.) and the overlying seawater column above the seawater-brine interface (3372 meter b.s.l.). The upper and lower portions of seawater-brine interface were sampled by two different Niskin bottles closed at 3379 and 3381 meter b.s.l., respectively (Supplementary Fig. 1).

When onboard, the Niskin content was immediately fractionated from the bottom tap in 1-liter aliquots showing increasing percentage salinity values measured by a hand refractometer (Atago, Japan). Due to sample amount limitations, in this study we did not perform the chemical characterization of the collected samples apart from measuring salinity values. Immediately after the fractioning, sample filtration was performed on GSWP 0.22 pore size filters (Millipore, Italy) and stored at $20^{\circ} \mathrm{C}$ until extraction. Sediment was collected deploying a box-corer, sampled with a sterile spatula, and stored in sterile bags at $4^{\circ} \mathrm{C}$ until enrichment cultures were setup.

\section{Molecular analyses of bacterial communities}

Total nucleic acids were extracted from each fraction as previously reported (Mapelli et al. 2013b).

Bacterial 16S rRNA gene fragments $(\sim 550 \mathrm{bp})$ were PCR amplified using primers 907R (3'-CCGTCAATT CCTTTGAGTTT-5') and GC-357F (3'-CCTACGGGA GGCAGCAG-5' with a $5^{\prime}$-end GC-clamp) targeting a portion of the 16S rRNA gene that includes the hypervariable V3-V5 regions (Muyzer et al. 1993). PCR reaction was performed as previously described (Marasco et al. 2012). For 16S rRNA Denaturing Gradient Gel Electrophoresis (DGGE), PCR products ( $100 \mathrm{ng})$ were loaded 
in a $0.7 \mathrm{~mm}$ polyacrylamide gel $(7 \% \mathrm{w} / \mathrm{v}$ acrylamidebisacrylamide, $37.5: 1$ ) containing $40 \%$ to $60 \%$ urea-formamide denaturing gradient $(100 \%$ corresponds to $7 \mathrm{M}$ urea and $40 \% \mathrm{v} / \mathrm{v}$ formamide). The gel run was performed for $17 \mathrm{~h}$ at $60^{\circ} \mathrm{C}$ by applying a constant voltage of $90 \mathrm{~V}$ in $1 \mathrm{X}$ Tris-acetate-EDTA (TAE) buffer. After electrophoresis, the gel was stained for $15 \mathrm{~min}$ in $1 \mathrm{X}$ TAE buffer containing 1X SYBR Green (Molecular Probes, Leiden, the Netherlands) according to manufacturer's instructions and rinsed three times for $10 \mathrm{~min}$ with distilled water. Gel images were captured using a Gel Doc 2000 apparatus (Bio-Rad, Milan, Italy). The band patterns of the PCRDGGE gel were analyzed using Image J software as previously described (Marasco et al. 2012).

The metabarcoding analysis targeting the 16S rRNA gene was carried out using bacterial universal primers (27F $\bmod 5^{\prime}-$ AGRGTTTGATCMTGGCTCAG - 3'; $519 \mathrm{R} \bmod$ bio $5^{\prime}-$ GTNTTACNGCGGCKGCTG - 3') targeting the variable regions of $16 \mathrm{~S}$ rRNA V1-V3 and amplifying a fragment of approximately $400 \mathrm{bp}$. PCR reactions and next-generation 454 pyrosequencing were performed outsourcing by MR DNA (Shallowater, TX, USA) as previously described (Bargiela et al. 2015). A total of 54278 raw, barcoded amplicons were obtained. The reads were trimmed to remove pyrosequencing adaptors and low-quality sequences $(<30$ Phred score) and size-selected (between 350 and $500 \mathrm{bp}$ ) using the QIIME (v 1.9.1) pipeline filtering scripts (Caporaso et al. 2010). After screening with Chimeras slayer, high-quality reads that were not flagged as chimeras were clustered into operational taxonomic units (OTUs), based on a sequence identity threshold of 97\%, using Uclust (Edgar 2010) and drawing one sequence for each OTU as representative. Sequences representative of each OTU were, then, taxonomically classified using the rdp classifier against the Silva database (v128) within QIIME.

To complement our taxonomy-based community analysis, we reconstructed predictive metagenomes from our 16S rRNA gene dataset using PICRUSt2 (https:// github.com/picrust/picrust2). For the analysis, OTUs were taxonomically identified, and a bacterial metagenome was predicted for each sample based on the genes content of the genome of the closest sequenced relative. The accuracy of metagenome predictions was measured by the Nearest Sequenced Taxon Index (NSTI), with lower values indicating a closer mean relationship (Langille et al. 2013). The metabolic predictions generated by PiCRUST2 were deemed reliable since the median NTSI were 0.132 for SW and 0.17 for T-1. The predicted genes were then assigned to metabolic pathways, and the distribution among samples of the reconstructed functional profiles was statistically compared using the chi-square test to identify the metabolisms significantly $(p<0.05)$ enriched or depleted in the analyzed samples, using STAMP (v 2.1.3; Parks et al. 2014; Parks and Beiko 2010).

\section{Bacteria isolation and identification from Tyro sediment}

An enrichment culture was established using the sediments collected from the Tyro basin as inoculum, ONR7a mineral medium and diesel oil as the sole carbon source, as previously described (Barbato et al. 2016a). Bacterial isolates have been obtained in pure cultures by plating on ONR7a solid medium ten-fold dilutions of the diesel oil enrichment, supplementing the Petri dishes with (i) diesel oil, (ii) octane, or (iii) dodecane as the sole carbon source. After purification, the isolates were streaked with and without the hydrocarbon molecules ( $\mathrm{HCs}$ ) used for the isolation and those able to grow exclusively in the presence of HCs were selected for further characterization.

The bacteria collection was dereplicated through internal transcribed spacer (ITS) PCR fingerprinting. ITS fingerprinting was performed as previously described (Mapelli et al. 2013a) using the primers ITS-F (3'-GTC GTAACAAGGTAGCCGTA- ${ }^{\prime}$ ) and ITS-R ( $3^{\prime}$-CTACGG CTAC CTTGTTACGA-5'). At least one isolate for each ITS group, established based on identical ITS fingerprinting, was identified by partial $16 \mathrm{~S}$ rRNA sequencing. The PCR amplification of the bacterial 16S rRNA gene was performed using the universal primer 27F ( $3^{\prime}$-AGA GTTTGATCMTGGCTCAG-5') and 1492R (3'-CTA CGGCTACCTTGTTACGA- $5^{\prime}$ ) as previously described (Mapelli et al., 2013a).

\section{Nucleotide sequence accession numbers}

Nucleotide sequences were edited in Chromas Lite 2.01 (http://www.technelysium.com.au) and subjected to a BLAST search (http://blast.ncbi.nlm.nih.gov/Blast.cgi). The partial 16S rRNA gene sequences obtained from the bacterial isolates are available at ENA under accession numbers LT935769, LT935770, LT935681 - LT935684.

All original non-chimeric 16S rRNA hypervariable tag 454 sequences are archived at the NCBI Short Read Archive (SRA) under the BioProject PRJNA742542, accession numbers SRR15047724 (T-1) and SRR15047723 (SW).

\section{Results}

\section{Bacterial community structure change along Tyro seawater-brine interface}

The salinity of Tyro seawater-brine interface samples collected in this work ranged between 5.6 and 20\%, while Tyro brine and deep seawater collected above the interface showed the salinity values of $28.8 \%$ and $4 \%$, respectively (Supplementary Table 1, Supplementary Fig. 1). PCR-DGGE fingerprinting described how the bacteria populations were stratified across the 
halocline, showing bands characterized by increasing or decreasing intensity according to the salinity value of the investigated layers, while other bands were detectable exclusively in specific samples (Fig. 1a). Principal component analysis (PCA) showed the sharp clustering of samples collected across the halocline in two groups (Fig. 1b), defined as upper and lower portions of the seawater-brine interface. The samples clustered along the $\mathrm{PC} 1$, which explains $44.72 \%$ of the described diversity. The upper interface group included halocline samples collected at salinity percentages comprised between 5.6 and $11.5 \%$, while those characterized by salinity values $13-20 \%$ formed the lower interface. According to statistical analysis, the two groups of samples hosted significantly different bacterial communities (PERMANOVA; $p=0.0209 ; t=2.0072$ ). Furthermore, PCA showed that deep seawater and brine were located outside the two groups. This segregation could be explained by the peculiar environmental characteristics, including the salinity values measured in this study.
Phylogenetic and functional diversity suggest specific bacterial communities adapted to the changing conditions occurring from the deep seawater to the upper seawater-brine interface

Based on the PCR-DGGE results, we selected one sample for each of the two identified salinity groups (i.e., T-1: 5.6\%; T-2: 13.2\%), in addition to overlaying seawater (SW) and brine (TB), for 16S rRNA gene high-throughput sequencing. 16S rRNA gene metabarcoding provided unsatisfactory results on samples $\mathrm{T}-2$ (lower interface) and $\mathrm{TB}$, possibly due to an incomplete removal of residual salts from the DNA extracts that could have played a negative effect on PCR results (Sankaranarayanan et al. 2011). On the other side, $16 \mathrm{~S}$ rRNA gene metabarcoding analysis generated 10735 and 15839 non-chimeric denoised reads in SW and T-1 samples, respectively. A total of $705 \mathrm{OTU}_{97}$ were identified, and the rarefaction curves showed that T-1 (upper interface) and SW samples reached saturation (Supplementary Fig. 2); thus, the phylogenetic and functional diversity of these two samples only are reported.
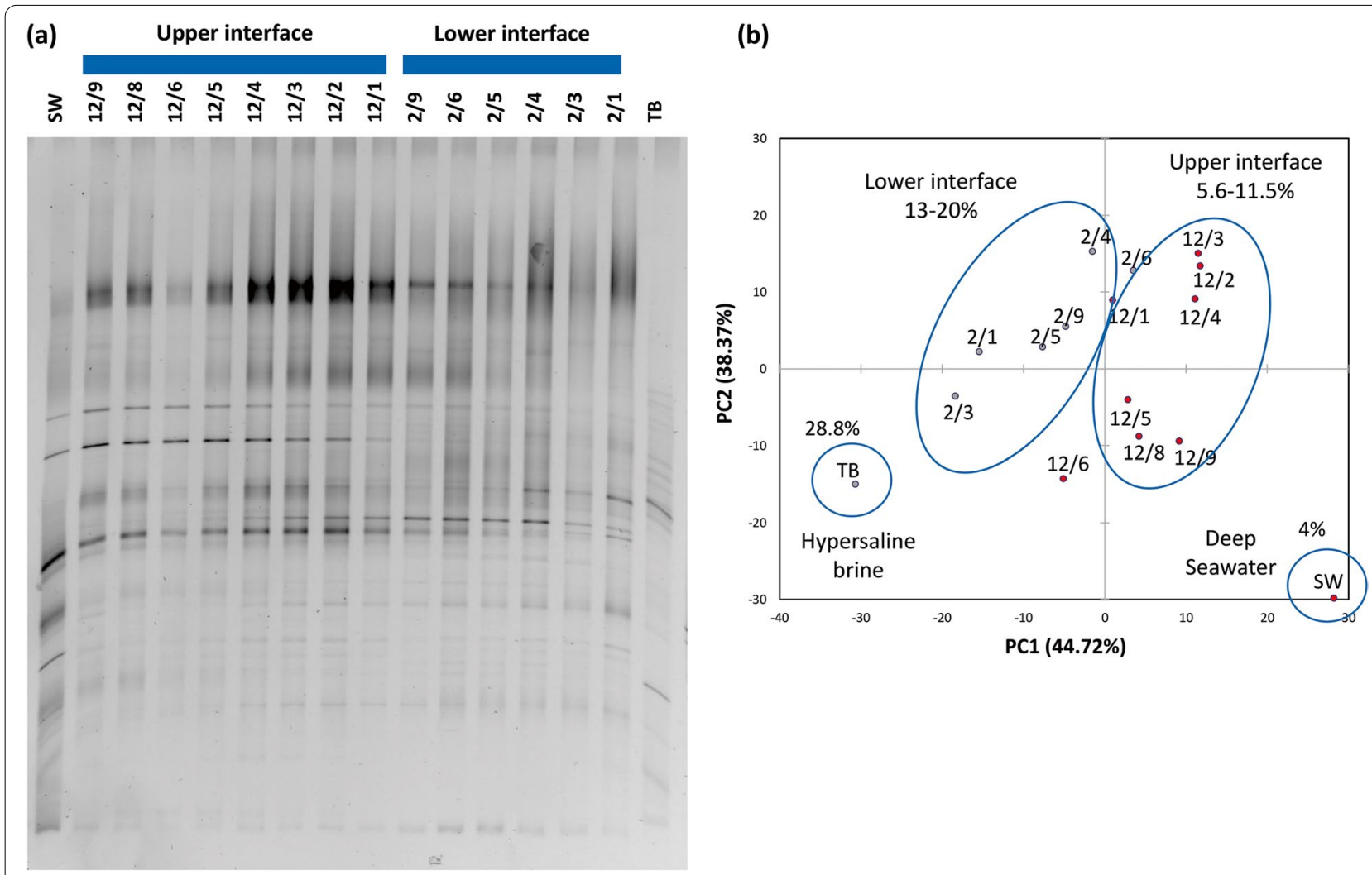

Fig. 1 Analysis of the bacterial community structure inhabiting Tyro brine, seawater-brine interface and deep seawater. A PCR-DGGE profiles based on the $16 \mathrm{~S}$ rRNA gene of the bacterial communities inhabiting deep seawater, Tyro brine and along Tyro seawater-brine interface. B PCA depicts the variation of bacterial community composition in the deep seawater, Tyro brine and along Tyro seawater-brine interface, identifying different clusters that correspond to the upper (5.6-11.5\% of salinity, T1) and lower (13-20\% of salinity, T2) portions of the seawater/brine interface 
The bacterial communities inhabiting deep seawater and the upper interface of Tyro encompassed different populations. The most abundant phylogenetic groups in deep seawater were Marinimicrobia-SAR406 clade (38.8\% of the total community), Proteobacteria (29.5\%), Actinobacteria (14\%), and Chloroflexi (8.3\%) (Fig. 2, Supplementary Fig. 1). The Proteobacteria phylum was mostly represented in SW by Deltaproteobacteria
(17.2\%), Alphaproteobacteria (6.3\%), and Gammaproteobacteria (5.3\%). The relative abundance of Actinobacteria and Chloroflexi sharply decreased in the upper Tyro halocline, where they represented $4.1 \%$ and $0.68 \%$ of the total bacterial community of sample T-1, respectively. Here, the predominant phyla were Proteobacteria (47.7\%), Bacteroidetes (20.8\%), Marinimicrobia-SAR406 clade (9.2\%), and Patescibacteria (4.9\%). Moreover, we

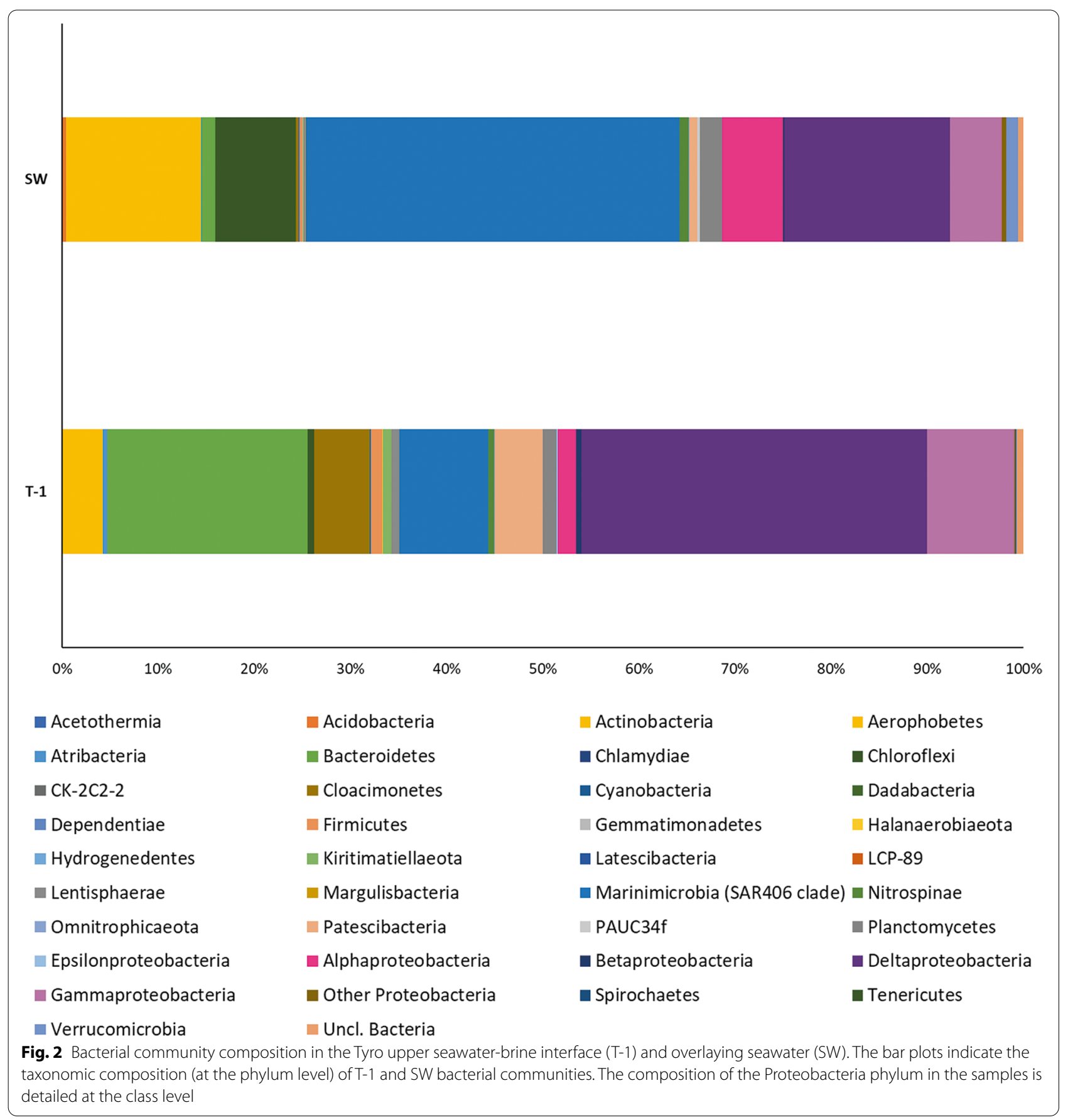


detected an increase of Deltaproteobacteria (35.9\%) and Gammaproteobacteria (9\%) compared to deep seawater, while Alphaproteobacteria decreased to $1.8 \%$ of the total bacterial community. The differential distribution of the above-mentioned phyla in the overlaying seawater and the upper interface of Tyro can be ascribed to the enrichment or depletion of specific classes and orders in the analyzed samples (Supplementary Table 2). Zooming in on Proteobacteria distribution in the two niches can be illustrative. The SAR342 clade within Deltaproteobacteria, for example, decreased from $11.6 \%$ of the total bacterial community in seawater to $8.2 \%$ in the upper interface, where the most abundant Deltaproteobacteria were affiliated to the order Desulfobacterales (25.5\%). Likewise, Thiomicrospirales, an order belonging to Gammaproteobacteria, decreased moving from seawater to the upper interface where the unclassified Gammaproteobacteria are predominant. Another example is the class Epsilonproteobacteria that was not detected in seawater while it appeared, though at a low percentage $(<1 \%$, Supplementary Table 2), in the bacterial community of the T-1 sample. On the contrary, other phyla were present at a similar percentage over the total bacterial community in SW and T1 samples, as in the case of Plantomycetes that represents $2.3 \%$ and $1.4 \%$, respectively.

The 16S rRNA gene sequences dataset generated in this work was used to infer functional diversity through PiCRUSt2 software. Among three-hundred-eighty-nine identified metabolic pathways (Supplementary Table 3), fifty were differently distributed $(p<0.05)$ in the analyzed samples (Fig. 3). The 1929 predicted enzymes and their EC numbers are reported in Supplementary Table 4. Noteworthy, the list includes several enzymes related to the synthesis of osmoprotectants (e.g., EC:4.2.1.108, ectoine synthase, EC:1.2.1.8 Betaine-aldehyde dehydrogenase, EC:1.1.99.1 choline dehydrogenase, EC:2.4.1.245 alpha,alpha-trehalose synthase, Supplementary Fig. 1). EC numbers referring to the alpha- and beta-glucosidases were present among the Tyro predicted bacterial enzymes (Supplementary Table 4). Several EC numbers referring to enzymes involved in the degradation of complex carbohydrates were also detected, primarily

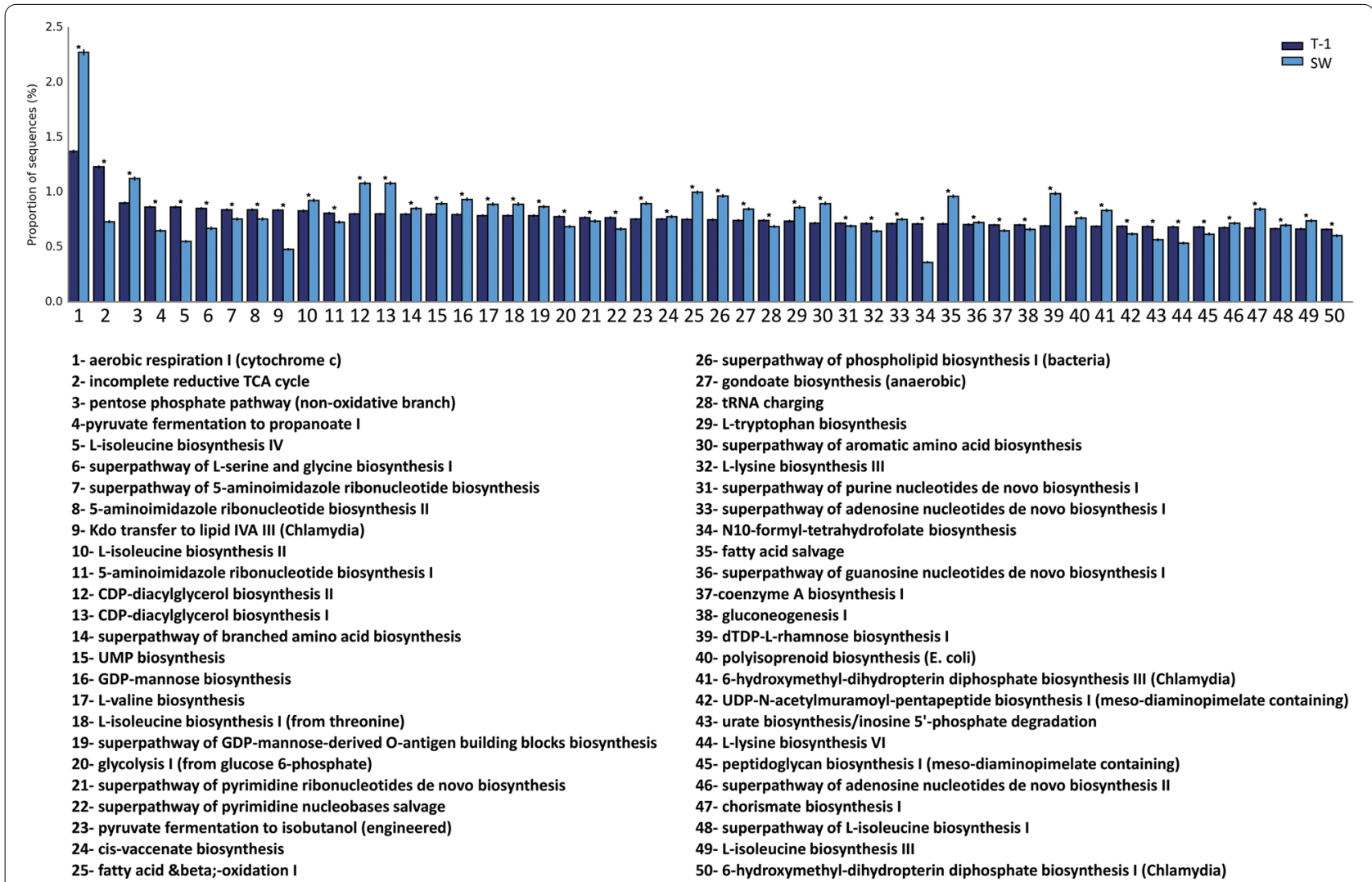

Fig. 3 Predicted metabolic pathways differentially distributed between the upper seawater-brine interface (T-1) and overlaying seawater (SW). Profile bar plot where blue and light blue bars indicate T-1 and SW samples, respectively. The significance of differential distribution ( $p<0.05)$ was assessed by chi-square test. The complete list of the metabolic pathways inferred by PiCRUSt2, including those not significantly distributed among samples, is reported in Supplementary Table 3 
in T-1 sample, and included EC:3.2.1.136 glucuronoarabinoxylan endo-1,4-beta-xylanase, EC:3.2.1.156 oligosaccharide reducing-end xylanase, EC:3.2.1.8 endo-1,4-beta-xylanase, EC:3.2.1.99 arabinan endo1,5-alpha-L-arabinosidase, EC:3.2.1.89 arabinogalactan endo-beta-1,4-galactanase, and EC:3.1.1.11 pectinesterase. In both T-1 and SW samples, we detected enzymes involved in the metabolism of methane and methylated compounds: EC:1.14.13.25 methane monooxygenase (soluble), EC:1.14.18.3 methane monooxygenase (particulate), EC:1.14.13.148 trimethylamine monooxygenase, EC:1.5.8.2 trimethylamine dehydrogenase, EC:1.5.8.1 dimethylamine dehydrogenase, and EC:1.1.2.7 methanol dehydrogenase (cytochrome c). Furthermore, EC numbers related to hydrocarbon degradation pathways were recorded in both the upper interface and the overlaying seawater (Supplementary Table 3, Supplementary Fig. 1). Though they were not significantly enriched or depleted according to the occurring conditions, EC:3.8.1.5 haloalkane dehalogenase was more represented in T-1 than seawater, whereas EC:1.14.14.5 alkanesulfonate monooxygenase and EC:1.14.15.3 alkane 1-monooxygenase showed the opposite trend (Supplementary Table 4).

\section{Hydrocarbonoclastic bacteria inhabit the Tyro sediment}

Thirty-eight bacteria were isolated from an enrichment culture established on mineral medium supplemented with diesel oil using Tyro sediment as inoculum. All the isolates kept in the collection were able to grow using hydrocarbons as the sole $\mathrm{C}$ source: twenty isolates were obtained plating the enrichment culture on solid medium and diesel oil, eleven in the presence of octane, while eight were isolated using dodecane. The three sub-collections differed exclusively for the hydrocarbons used during the last step of the isolation procedure. Bacterial isolates were genotyped, and we identified six (diesel oil), two (octane), and four (dodecane) internal transcribed spacer (ITS) groups in the collections. The twelve representatives of each ITS group, identified by $16 \mathrm{~S}$ rRNA gene sequencing, were classified as Actinobacteria or Proteobacteria, the latter including isolates in the Alphaand Gammaproteobacteria classes (Table 1). Both phyla were present in the diesel oil-enriched strain collection, while the use of dodecane and octane as sole $\mathrm{C}$ source allowed to bring into culture exclusively Actinobacteria and Gammaproteobacteria, respectively. The taxonomic identification of the strains showed that the established collection includes the bacterial genera Dietzia, Marinobacter, Arthrobacter, Labrenzia, and Micrococcus (Table 1).

\section{Discussion}

Molecular fingerprintings remain informative options for the description of beta-diversity and correlation analyses between bacterial community structure and environmental parameters, generating outputs comparable to those obtained applying pyrosequencing methods (Gobet et al. 2014; van Dorst et al. 2014), though they are not considered suitable tools for the phylogenetic description of bacterial communities. In this study, the results of the PCR-DGGE molecular fingerprinting showed that bacterial communities of Tyro are stratified across the halocline and clearly separated from the brine and the overlaying seawater, in agreement with the data reported by several studies about the prokaryotic communities' structure in DHAB interfaces located in the Eastern Mediterranean sea (Borin et al. 2009; Daffonchio et al. 2006; Yakimov et al. 2007)

Table 1 List of bacteria isolated from Tyro sediment. For each isolate, the closest described bacterial species is indicated together with its accession number in the public database NCBI. The percentage of $16 \mathrm{~S}$ rRNA gene sequence identity is indicated, as well as the environment from which the closest described spp. was isolated

\begin{tabular}{|c|c|c|c|c|c|}
\hline Isolate & Phylum/class & Closest described sp. & acc. $n^{\circ}$ & id (\%) & Reference environ \\
\hline T_2 & Actinobacteria & Arthrobacter crystallopoietes & KC456536 & 99 & Activated sludge \\
\hline T_4 & Actinobacteria & Arthrobacter crystallopoietes & KC456536 & 99 & Activated sludge \\
\hline T_7 & Alphaproteobacteria & Labrenzia alba & MZ328875 & 99 & Marine sponge \\
\hline$T_{-} 17$ & Alphaproteobacteria & Labrenzia alba & MZ328875 & 99 & Marine sponge \\
\hline$T_{-} 19$ & Alphaproteobacteria & Labrenzia alba & KY787142 & 99 & Posidonia oceanica \\
\hline T_20 & Alphaproteobacteria & Labrenzia alba & KY787142 & 99 & Posidonia oceanica \\
\hline $\mathrm{T}-\mathrm{C} 12-03$ & Actinobacteria & Dietzia cinnamea & NR_116686 & 97 & Clinical swab \\
\hline $\mathrm{T}-\mathrm{C} 12-04$ & Actinobacteria & Micrococcus yunnanensis & LT160814 & 98 & Carp \\
\hline $\mathrm{T}-\mathrm{C} 12-05$ & Actinobacteria & Micrococcus yunnanensis & KX108875 & 99 & Soil \\
\hline $\mathrm{T}-\mathrm{C} 12-07$ & Actinobacteria & Dietzia cinnamea & KP345927 & 98 & - \\
\hline $\mathrm{T}-\mathrm{C} 8-02$ & Gammaproteobacteria & Marinobacter adhaerens & MW675179 & 99 & Mariana Trench \\
\hline $\mathrm{T}-\mathrm{C} 8-10$ & Gammaproteobacteria & Marinobacter adhaerens & MW675179 & 99 & Mariana Trench \\
\hline
\end{tabular}


and the Red Sea (Michoud et al. 2021; Ngugi et al. 2015). Likewise, terminal restriction fragment length polymorphism (T-RFLP, Filker et al. 2013) applied to study protist diversity in different Eastern Mediterranean DHABs showed that brine and interface samples hosted different communities, as later confirmed by pyrosequencing of the V4 rRNA subunit (Stock et al. 2013). Unraveling the relationship between the eukaryotic community structure and the occurring chemical parameters in the Tyro basin, the main drivers of eukaryotes' distribution were identified as oxygen concentration, sulfide concentration, and salinity (Filker et al. 2013). A significant correlation between the bacterial community structure and salinity across the fractioned Tyro seawater-brine interface was detected in this study, in agreement with the role of salinity as driver of bacterial community structure in other thalassohaline DHABs, such as Urania and Bannock (Borin et al. 2009; Daffonchio et al. 2006). Halophilic bacteria face salinity stress through different strategies named "salt-in" and "salt-out" mechanisms (Fisher et al. 2021). In this study, prediction of functions from the pyrosequencing data suggests the importance of compatible solutes (i.e., ectoine, betaine, choline, and trehalose) synthesis and accumulation as osmoprotective metabolites, in agreement with previous findings based on genomic and physiological information on bacterial strains isolated from Eastern Mediterranean and Red Sea DHABs (Antunes et al. 2011; Zeaiter et al. 2019).

The upper seawater-brine interface of Tyro hosts bacterial phyla commonly found in others Eastern Mediterranean DHABs. Bacteroidetes, which are highly abundant in the Tyro interface, were described in DHABs using both cultivation-dependent (Daffonchio et al. 2006) and molecular techniques (Borin et al. 2009; Yakimov et al. 2007). Previous literature shows that the distribution of Proteobacteria classes, consistently representing a large fraction of the prokaryotic microbiome along DHAB interfaces as reported for Tyro in this study, is different according to the considered basin. For instance, Delta- and Epsilonproteobacteria dominate Urania haloclines (Borin et al. 2009). The latter Class dominates Thetis interface (Ferrer et al. 2012) while it has not been reported in the Medee lake, being replaced by Gammaproteobacteria (Yakimov et al. 2013). Likewise, the Tyro halocline hosts predominantly Deltaproteobacteria and Gammaproteobacteria, while Epsilonproteobacteria were detected only at a low percentage. The lack of detailed information on the profile of geochemical species along the Tyro halocline and the information inferred from the 16S rRNA gene sequence dataset in this study do not allow to elucidate the ecological role played by the detected bacterial taxa, although the presence of certain phylogenetic groups (i.e., Desulfobacterales, Desulfarculales) suggests the possible importance of sulfur species respirations, also reported for other DHABs (Borin et al. 2009; Van Der Wielen and Heijs 2007).

Among Planctomycetes, we report the presence of $16 \mathrm{~S}$ rRNA sequences affiliated to the Brocadia order that includes anaerobic ammonium oxidizing (ANAMMOX) bacteria previously identified in the haloclines of Bannock and L'Atalante basins (Borin et al. 2013) and the Suakin Deep in the Red Sea (Michoud et al. 2021).

In this study, enzymes related to the utilization of a large repertoire of carbon sources were predicted to occur across the Tyro halocline by PiCRUSt 2 analysis, in agreement with the genetic information available for different prokaryotic strains previously isolated from DHABs. The list includes several enzymes involved in C1-compounds metabolisms, presumably important in the Tyro upper seawater-brine interface, in agreement with the isolation of the novel piezophilic and halophilic methanogenic species Methanohalophilus profundi, recently proposed to be implicated in the biogenic formation of methane in DHABs (L'Haridon et al. 2020). In both $\mathrm{SW}$ and $\mathrm{T}-1$ samples, we detected sequence signatures of the Methylococcales order, which includes aerobic methanotrophic bacteria recently retrieved in the seawater-brine interface of the Kryos basin (Steinle et al. 2018), and adapted to micro-oxic conditions in both thalassohaline and athalassohaline DHABs. Furthermore, EC numbers of alpha- and beta-glucosidases detected in the genome sequence of Virgibacillus sp. 21D, a highly adapted bacterial strain isolated from the seawater-brine interface of the Discovery DHAB in the Mediterranean Sea, were retrieved (Zeaiter et al. 2019). Lignocellulose-degrading enzymes involved in the degradation of complex carbon compounds possibly deriving from algae or seagrass cell walls were also included in the list of predicted enzymes found in T-1 samples. Genetic information related to these enzymes were previously reported for an archaeal species (i.e., Halorhabdus tiamatea) isolated from DHABs and proposed as a potential polysaccharide degrader (Werner et al. 2014). We speculate that a similar function could be enriched in the Tyro upper interface, where debris can accumulate after sinking. Finally, in agreement with the possible hydrocarbon inputs in DHABs from the bottom sediments (Merlino et al. 2018), metabolic pathways and genes related to hydrocarbon degradation were retrieved from the bacterial communities inhabiting the Tyro basin.

Hydrocarbons in DHABs sediment can be derived from the adjacent geological layers (Brusa et al. 2001) and can sink through the DHAB water column and accumulate in 
the sediments. The deposition of aliphatic and aromatic compounds of both natural and anthropogenic origin has been documented in Eastern Mediterranean sea deepsea sediments (Parinos et al. 2013). Hence, we opted to use a sediment sample collected from Tyro for searching of hydrocarbonoclastic bacteria by a culture-dependent approach. Some of the isolated bacterial genera were previously described for their ability to degrade hydrocarbons in marine ecosystems, including deep-sea, like Dietzia (Wang et al. 2014) and Marinobacter (Sun et al. 2020; Zhou et al. 2020). Members of the Marinobacteraceae family were also retrieved in the seawater overlaying the Tyro basin, according to the 16S rRNA gene metabarcoding analysis conducted in this study. Neither Alcanivorax spp. nor other major members of oil-degrading bacterial communities easily blooming in surface waters (e.g., Oleiphilus, Neptunomonas, Oleispira) were retrieved in the hydrocarbon-degrading culture collection from Tyro sediments, in agreement with the so-called "Alcanivorax paradox" postulating the impairing effects of hydrostatic pressure on this oil-degrading bacterial genus (Scoma et al. 2016). The differentiation of certain HC degraders among "surface" and "deep" ecotypes was suggested, as already described for Alteromonas macleodii (Liu et al. 2019), one of the bacterial species previously isolated from the seawater-brine interface of Urania DHAB (Sass et al. 2001). The hydrocarbonoclastic bacterial strains isolated in the current study join the portfolio of cultured marine microorganisms potentially exploitable for biotechnology related to oil removal from polluted marine sites. In particular, after the experimental validation of the ability to degrade hydrocarbons under high hydrostatic pressure, they could be potential resources for bioremediation at high depth (Mapelli et al. 2017b).

\section{Conclusions}

This study provides an initial overview of the bacterial community structure of the Tyro basin, the only DHAB in the Eastern Mediterranean sea not yet characterized for its bacterial microbiome, suggesting that the seawater-brine interface hosts a prokaryotic microbiome adapted to the changing environmental conditions of the halocline at the seawater/brine interface, as previously indicated for micro-eukaryotes. The study identified bacterial communities in Tyro potentially involved in key metabolisms supporting the element cycles in this polyextreme ecosystem that deserves further studies for a more detailed characterization and indicates Tyro sediment as an explorable source of culturable species of potential interest for biotechnological applications in marine bioremediation.

\section{Supplementary Information}

The online version contains supplementary material available at https://doi. org/10.1186/s13213-022-01667-7.

Additional file 1: Supplementary Figure 1. Schematic representation of Tyro sample collection and bacterial diversity information. On the left, the figure indicates at which depth each Niskin bottles have been closed to collect seawater, upper and lower seawater-brine interface and brine samples, reporting the range of salinity values for each microhabitat.

Main taxonomic and functional information generated by 165 rRNA gene sequencing is reported for seawater and upper seawater-brine interface samples.

Additional file 2: Supplementary Figure 2. Rarefaction curve of the $16 \mathrm{~S}$ rRNA gene libraries. Rarefaction curves were calculated and showed that both T-1 and SW samples reached saturation in terms of Shannon diversity of the observed species.

Additional file 3: Supplementary Table 1. List of analyzed samples. The list includes the code of each analyzed samples, as indicated in the text, and the correspondent salinity. SW: seawater; TB: Tyro brine. Supplementary Table 2. Relative abundance of the taxonomic groups identified in seawater (SW) and the upper interface of the Tyro DHAB (T-1). Taxonomic identification of OTU $\mathrm{OT}_{97}$ were aggregated and reported at the Family level. Unc. $=$ uncultured; Bact=bacterium.

Additional file 4: Supplementary Table 3. List of the metabolic pathways identified by PICRUST2 in seawater (SW) and upper interface of the Tyro DHAB (T-1). The Excel file includes the complete list of metabolisms detected in at least one of the two samples. The table also reports the abundance of each pathway estimated by PiCRUST2 using the read depth for each OTU and the predicted pathway abundance for the same OTU. Supplementary Table 4. List of the predicted enzymes identified by PICRUST2 in seawater (SW) and upper interface of the Tyro DHAB

(T-1). The Excel file provides the complete list of the enzymatic function detected in at least one of the two samples and indicated according to the EC numbers. The table also reports the abundance of each function (i.e., enzyme) estimated by PICRUST from the read depth for each OTU and the predicted function abundances per for the same OTU.

\section{Acknowledgements}

We thank the master and crew of the R/V Urania for excellent technical assistance during sampling activities.

\section{Authors' contributions}

SB and FM conceived the study. FM collected the samples. MB, FM, BC, and VR performed the experiments and analyzed the data. FM wrote the first version of the manuscript. SB and DD supported the research. All authors critically revised the manuscript and have approved its content.

\section{Funding}

This work was financially supported by the EU FP-7 projects ULIXES (Grant agreement N. 266473) and KILLSPILL (Grant agreement N. 312139). DD has been supported by the baseline fund provided by the King Abdullah University of Science and Technology.

\section{Availability of data and materials}

Data related to DNA sequencing are made available through public databases as specified in the "Materials and methods" section.

\section{Declarations}

Ethics approval and consent to participate Not applicable.

Consent for publication

All of the authors consent to the publication of this manuscript in Annals of Microbiology. 


\section{Competing interests}

The authors declare that they have no competing interests.

\section{Author details}

${ }^{1}$ Department of Food, Environmental and Nutritional Sciences (DeFENS), University of Milan, Via Celoria 2, 20133 Milan, Italy. ${ }^{2}$ Present address: Section of Microbiology, Department of Biology, Aarhus University, Ny Munkegade 116, 8000 Aarhus, Denmark. ${ }^{3}$ Department of Environmental Sciences, Informatics and Statistics, Ca' Foscari University of Venice, Venice, Italy. ${ }^{4}$ Red Sea Research Center (RSRC), Biological and Environmental Sciences and Engineering Division (BESE), King Abdullah University of Science and Technology (KAUST), Thuwal 23955-6900, Saudi Arabia.

\section{Received: 15 December 2021 Accepted: 10 February 2022}

Published online: 27 February 2022

\section{References}

Antunes A, Alam I, Bajic VB, Stingl U (2011) Genome sequence of salinisphaera shabanensis, a gammaproteobacterium from the harsh, variable environment of the brine-seawater interface of the shaban deep in the red sea. J Bacteriol 193:4555-4556. https://doi.org/10.1128/JB.05459-11

Barbato M, Mapelli F, Magagnini M, Chouaia B, Armeni M, Marasco R, Crotti E, Daffonchio D, Borin S (2016a) Hydrocarbon pollutants shape bacterial community assembly of harbor sediments. Mar Pollut Bull 104:211-220

Barbato M, Scoma A (2020) Mild hydrostatic-pressure (15 MPa) affects the assembly, but not the growth, of oil-degrading coastal microbial communities tested under limiting conditions $\left(5^{\circ} \mathrm{C}\right.$, no added nutrients). FEMS Microbiol Ecol 96:1-12. https://doi.org/10.1093/femsec/fiaa160

Barbato M, Scoma A, Mapelli F, De Smet R, Banat IM, Daffonchio D, Boon N, Borin S (2016b) Hydrocarbonoclastic Alcanivorax isolates exhibit different physiological and expression responses to $\mathrm{n}$-dodecane. Front Microbiol 7:1-14. https://doi.org/10.3389/fmicb.2016.02056

Bargiela R, Mapelli F, Rojo D, Chouaia B, Tornés J, Borin S, Richter M, Del Pozo MV, Cappello S, Gertler C, Genovese M, Denaro R, Martínez-Martínez M, Fodelianakis S, Amer RA, Bigazzi D, Han X, Chen J, Chernikova TN Golyshina OV, Mahjoubi M, Jaouanil A, Benzha F, Magagnini M, Hussein E, Al-Horani F, Cherif A, Blaghen M, Abdel-Fattah YR, Kalogerakis N, Barbas C, Malkawi HI, Golyshin PN, Yakimov MM, Daffonchio D, Ferrer M (2015) Bacterial population and biodegradation potential in chronically crude oil-contaminated marine sediments are strongly linked to temperature. Sci Rep 5:11651. https://doi.org/10.1038/srep11651

Borin S, Brusetti L, Mapelli F, D'Auria G, Brusa T, Marzorati M, Rizzi A, Yakimov M, Marty D, De Lange GJ, Van Der Wielen P, Bolhuis H, McGenity TJ, Polymenakou PN, Malinverno E, Giuliano L, Corselli C, Daffonchio D (2009) Sulfur cycling and methanogenesis primarily drive microbial colonization of the highly sulfidic Urania deep hypersaline basin. Proc Natl Acad Sci U S A 106. https://doi.org/10.1073/pnas.0811984106

Borin S, Mapelli F, Rolli E, Song B, Tobias C, Schmid MC, De Lange GJ, Reichart GJ, Schouten S, Jetten M, Daffonchio D (2013) Anammox bacteria populations in deep marine hypersaline gradient systems. Extremophiles 17:289-299

Brusa T, Borin S, Ferrari F, Sorlini C, Corselli C, Daffonchio D (2001) Aromatic hydrocarbon degradation patterns and catechol 2,3-dioxygenase genes. Microbiol Res 156:49-57

Caporaso JG, Kuczynski J, Stombaugh J, Bittinger K, Bushman FD, Costello EK, Fierer N, Peña AG, Goodrich JK, Gordon Jl, Huttley GA, Kelley ST, Knights D, Koenig JE, Ley RE, Lozupone CA, McDonald D, Muegge BD, Pirrung M, Reeder J, Sevinsky JR, Turnbaugh PJ, Walters WA, Widmann J, Yatsunenko T, Zaneveld J, Knight R (2010) QIIME allows analysis of high-throughput community sequencing data. Nat. Methods 7, 335-336. https://doi.org/ 10.1038/nmeth.f.303.

De Lange GJ, Middelburg JJ, Van Der Weijden CH, Catalano G, Luther GW III, Hydes DJ, Woittiez JRW, Klinkhammer GP (1990) Composition of anoxic hypersaline brines in the Tyro and Bannock Basins, eastern Mediterranean. Mar Chem 31:63-88

Daffonchio D, Borin S, Brusa T, Brusetti L, Van Der Wielen PWJJ, Bolhuis H, Yakimov MM, D'Auria G, Giuliano L, Marty D, Tamburini C, McGenity TJ, Hallsworth JE, Sass AM, Timmis KN, Tselepides A, De Lange GJ, Hübner A,
Thomson J, Varnavas SP, Gasparoni F, Gerber HW, Malinverno E, Corselli C, Garcin J, McKew B, Golyshin PN, Lampadariou N, Polymenakou P, Calore D, Cenedese S, Zanon F, Hoog S (2006) Stratified prokaryote network in the oxic-anoxic transition of a deep-sea halocline. Nature 440:203-207. https://doi.org/10.1038/nature04418

Edgar RC (2010). Search and clustering orders of magnitude faster than BLAST. Bioinformatics 26, 2460-2461. https://doi.org/10.1093/bioinformatics/ btq461.

Ferrer M, Werner J, Chernikova TN, Bargiela R, Fernández L, La Cono V, Waldmann J, Teeling H, Golyshina OV, Glöckner FO, Yakimov MM, Golyshin PN (2012) Unveiling microbial life in the new deep-sea hypersaline Lake Thetis. Part II: A metagenomic study. Environ Microbiol 14:268-281. https:// doi.org/10.1111/j.1462-2920.2011.02634.x

Filker S, Stock A, Breiner HW, Edgcomb V, Orsi W, Yakimov MM, Stoeck T (2013) Environmental selection of protistan plankton communities in hypersaline anoxic deep-sea basins, Eastern Mediterranean Sea. Microbiologyopen 2:54-63. https://doi.org/10.1002/mbo3.56

Fisher LA, Pontefract A, Som M, Carr S, Klempay CE, Schmidt BE, Bowman JS, Bartlett DH (2021) Current state of athalassohaline deep-sea hypersaline anoxic basin research-recommendations for future work and relevance to astrobiology. Environ Microbiol 23:3360-3369. https://doi.org/10.1111/ 1462-2920.15414

Gobet A, Boetius A, Ramette A (2014) Ecological coherence of diversity patterns derived from classical fingerprinting and Next Generation Sequencing techniques. Environ Microbiol 16:2672-2681. https://doi.org/10.1111/ 1462-2920.12308

L'Haridon S, Haroun H, Corre E, Roussel E, Chalopin M, Pignet P, Balière C, la Cono V, Jebbar M, Yakimov M, Toffin L (2020) Methanohalophilus profundi sp. nov., a methylotrophic halophilic piezophilic methanogen isolated from a deep hypersaline anoxic basin. Syst Appl Microbiol 43:126107. https://doi.org/10.1016/j.syapm.2020.126107

La Cono V, Bortoluzzi G, Messina E, La Spada G, Smedile F, Giuliano L, Borghini M, Stumpp C, Schmitt-Kopplin P, Harir M, O'Neill WK, Hallsworth JE, Yakimov M (2019) The discovery of Lake Hephaestus, the youngest athalassohaline deep-sea formation on Earth. Sci Rep 9:1-11. https://doi.org/ 10.1038/s41598-018-38444-z

La Cono V, Smedile F, Bortoluzzi G, Arcadi E, Maimone G, Messina E, Borghini M, Oliveri E, Mazzola S, L'Haridon S, Toffin L, Genovese L, Ferrer M, Giuliano L, Golyshin PN, Yakimov MM (2011) Unveiling microbial life in new deep-sea hypersaline Lake Thetis. Part I: Prokaryotes and environmental settings. Environ Microbiol 13:2250-2268. https://doi.org/10.1111/j.1462-2920. 2011.02478.x

Langille MGl, Zaneveld J, Caporaso JG, McDonald D, Knights D, Reyes JA, Clemente JC, Burkepile DE, Vega Thurber RL, Knight R, Beiko RG, Huttenhower $C$ (2013) Predictive functional profiling of microbial communities using 16S rRNA marker gene sequences. Nat Biotechnol 31:814-821. https:// doi.org/10.1038/nbt.2676

Liu J, Zheng Y, Lin H, Wang X, Li M, Liu Y, Yu M, Zhao M, Pedentchouk N, LeaSmith DJ, Todd JD, Magill CR, Zhang WJ, Zhou S, Song D, Zhong H, Xin Y, Yu M, Tian J, Zhang XH (2019) Proliferation of hydrocarbon-degrading microbes at the bottom of the Mariana Trench. Microbiome 7:1-13. https://doi.org/10.1186/s40168-019-0652-3

Mapelli F, Barozzi A, Michoud G, Merlino G, Crotti E, Borin S, Daffonchio D (2017a) An updated view of the microbial diversity in deep hypersaline anoxic basins, Adaption of Microbial Life to Environmental Extremes: Novel Research Results and Application, 2nd edn. https://doi.org/10. 1007/978-3-319-48327-6 2

Mapelli F, Varela MM, Barbato M, Alvariño R, Fusi M, Álvarez M, Merlino G, Daffonchio D, Borin S (2013b) Biogeography of planktonic bacterial communities across the whole Mediterranean Sea. Ocean Sci 9:585-595. https://doi.org/10.5194/os-9-585-2013

Mapelli F, Marasco R, Rolli E, Barbato M, Cherif H, Guesmi A, Ouzari I, Daffonchio D, Borin S (2013a) Potential for plant growth promotion of rhizobacteria associated with Salicornia growing in Tunisian hypersaline soils. Biomed Res Int. 2013, 248078. https://doi.org/10.1155/2013/248078.

Mapelli F, Scoma A, Michoud G, Aulenta F, Boon N, Borin S, Kalogerakis N, Daffonchio D (2017b) Biotechnologies for marine oil spill cleanup: indissoluble ties with microorganisms. Trends Biotechnol. https://doi.org/10. 1016/j.tibtech.2017.04.003

Marasco R, Rolli E, Ettoumi B, Vigani G, Mapelli F, et al. (2012) A Drought Resistance-Promoting Microbiome Is Selected by Root System under 
Desert Farming. PLoS ONE 7(10): e48479. https://doi.org/10.1371/journal. pone. 0048479 .

Merlino G, Barozzi A, Michoud G, Ngugi DK, Daffonchio D (2018) Microbial ecology of deep-sea hypersaline anoxic basins. FEMS Microbiol Ecol 94:1-15. https://doi.org/10.1093/femsec/fiy085

Michoud G, Ngugi DK, Barozzi A, Merlino G, Calleja ML, Delgado-Huertas A, Morán XAG, Daffonchio D (2021) Fine-scale metabolic discontinuity in a stratified prokaryote microbiome of a Red Sea deep halocline. ISME J 15:2351-2365. https://doi.org/10.1038/s41396-021-00931-z

Muyzer G, Dewa al E, Uitterlinden A (1993). Profiling of complex microbialpopulations by denaturing gradient gelelectrophoresis analysis of polymerase chain reaction-amplified genes-coding for $16 \mathrm{~S}$ ribosomal-RNA. Appl Environ Microbiol. 59, 695-700.

Ngugi DK, Blom J, Alam I, Rashid M, Ba-Alawi W, Zhang G, Hikmawan T, Guan Y, Antunes A, Siam R, El Dorry H, Bajic V, Stingl U (2015) Comparative genomics reveals adaptations of a halotolerant thaumarchaeon in the interfaces of brine pools in the Red Sea. ISME J 9:396-411. https://doi. org/10.1038/ismej.2014.137

Parinos C, Gogou A, Bouloubassi I, Pedrosa-Pàmies R, Hatzianestis I, SanchezVidal A, Rousakis G, Velaoras D, Krokos G, Lykousis V (2013) Occurrence, sources and transport pathways of natural and anthropogenic hydrocarbons in deep-sea sediments of the eastern Mediterranean Sea. Biogeosciences 10:6069-6089. https://doi.org/10.5194/bg-10-6069-2013

Parks DH, Beiko RG (2010) Identifying biologically relevant differences between metagenomic communities. Bioinformatics 26:715-721. https:// doi.org/10.1093/bioinformatics/btq041

Parks DH, Tyson GW, Hugenholtz P, Beiko RG (2014) STAMP: Statistical analysis of taxonomic and functional profiles. Bioinformatics 30:3123-3124. https://doi.org/10.1093/bioinformatics/btu494

Sankaranarayanan K, Timofeeff MN, Spathis R, Lowenstein TK, Lum JK (2011) Ancient microbes from halite fluid inclusions: optimized surface sterilization and DNA extraction. PLoS One 6(6):e20683. https://doi.org/10.1371/ journal.pone.0020683

Sass AM, Sass H, Coolen MJL, Cypionka H, Overmann J (2001) Microbial communities in the chemocline of a hypersaline deep-sea basin (Urania Basin, Mediterranean Sea). Appl Environ Microbiol 67:5392-5402. https://doi. org/10.1128/AEM.67.12.5392-5402.2001

Scoma A, Yakimov MM, Boon N (2016) Challenging oil bioremediation at deep-sea hydrostatic pressure. Front Microbiol 7:1203. https://doi.org/10. 3389/fmicb.2016.01203

Steinle L, Knittel K, Felber N, Casalino C, De Lange G, Tessarolo C, Stadnitskaia A, Sinninghe Damsté JS, Zopfi J, Lehmann MF, Treude T, Niemann $H$ (2018) Life on the edge: active microbial communities in the Kryos MgCl2-brine basin at very low water activity. ISME J 12:1414-1426. https://doi.org/10.1038/s41396-018-0107-z

Stock A, Edgcomb V, Orsi W, Filker S, Breiner HW, Yakimov MM, Stoeck T (2013) Evidence for isolated evolution of deep-sea ciliate communities through geological separation and environmental selection. BMC Microbiol 13:1. https://doi.org/10.1186/1471-2180-13-150

Sun QL, Sun YL, Sun YY, Luan ZD, Lian C (2020) Marinobacter fonticola sp. Nov., isolated from deep sea cold seep sediment. Int I Syst Evol Microbiol 70:1172-1177. https://doi.org/10.1099/ijsem.0.003895

Van Der Wielen PWJJ, Bolhuis H, Borin S, Daffonchio D, Corselli C, Giuliano L, D'Auria G, De Lange GJ, Huebner A, Varnavas SP, Thomson J, Tamburini C, Marty D, McGenity TJ, Timmis KN (2005) The enigma of prokaryotic life in deep hypersaline anoxic basins. Science (80- ) 307:121-123. https://doi, org/10.1126/science.1103569

Van Der Wielen PWJJ, Heijs SK (2007) Sulfate-reducing prokaryotic communities in two deep hypersaline anoxic basins in the Eastern Mediterranean deep sea: brief report. Environ Microbiol 9:1335-1340. https://doi.org/10. 1111/j.1462-2920.2006.01210.x

van Dorst J, Bissett A, Palmer AS, Brown M, Snape I, Stark JS, Raymond B, McKinlay J, Ji M, Winsley T, Ferrari BC (2014) Community fingerprinting in a sequencing world. FEMS Microbiol Ecol 89:316-330. https://doi.org/10. 1111/1574-6941.12308

Varrella S, Tangherlini M, Corinaldesi C (2020) Deep hypersaline anoxic basins as untapped reservoir of polyextremophilic prokaryotes of biotechnological interest. Mar Drugs 18:1-32. https://doi.org/10.3390/md18020091

Wang W, Cai B, Shao Z (2014) Oil degradation and biosurfactant production by the deep sea bacterium Dietzia maris As-13-3. Front Microbiol 5:1-11. https://doi.org/10.3389/fmicb.2014.00711
Werner J, Ferrer M, Michel G, Mann AJ, Huang S, Juarez S, Ciordia S, Albar JP, Alcaide M, La Cono V, Yakimov MM, Antunes A, Taborda M, da Costa MS, Hai T, Glöckner FO, Golyshina OV, Golyshin PN, Teeling H (2014) Halorhabdus tiamatea: proteogenomics and glycosidase activity measurements identify the first cultivated euryarchaeon from a deep-sea anoxic brine lake as potential polysaccharide degrader. Environ Microbiol 16:25252537. https://doi.org/10.1111/1462-2920.12393

Yakimov MM, La Cono V, Denaro R, D'Auria G, Decembrini F, Timmis KN, Golyshin PN, Giuliano L (2007) Primary producing prokaryotic communities of brine, interface and seawater above the halocline of deep anoxic lake L'Atalante, Eastern Mediterranean Sea. ISME J 1:743-755. https://doi.org/ 10.1038/ismej.2007.83

Yakimov MM, La Cono V, Slepak VZ, La Spada G, Arcadi E, Messina E, Borghini M, Monticelli LS, Rojo D, Barbas C, Golyshina OV, Ferrer M, Golyshin PN, Giuliano L (2013) Microbial life in the Lake Medee, the largest deep-sea salt-saturated formation. Sci Rep 3:1-9. https://doi.org/10.1038/srep0 3554

Yakimov MM, La Cono V, Spada GL, Bortoluzzi G, Messina E, Smedile F, Arcadi E, Borghini M, Ferrer M, Schmitt-Kopplin P, Hertkorn N, Cray JA, Hallsworth JE, Golyshin PN, Giuliano L (2015) Microbial community of the deep-sea brine Lake Kryos seawater-brine interface is active below the chaotropicity limit of life as revealed by recovery of mRNA. Environ Microbiol 17:364-382. https://doi.org/10.1111/1462-2920.12587

Zeaiter Z, Marasco R, Booth JM, Prosdocimi EM, Mapelli F, Callegari M, Fusi M, Michoud G, Molinari F, Daffonchio D, Borin S, Crotti E (2019) Phenomics and genomics reveal adaptation of Virgibacillus dokdonensis strain 21D to its origin of isolation, the seawater-brine interface of the mediterranean sea deep hypersaline anoxic basin discovery. Front Microbiol 10. https://doi.org/10.3389/fmicb.2019.01304

Zhou M, Dong B, Shao Z (2020) Complete genome sequence of Marinobacter sp. LQ44, a haloalkaliphilic phenol-degrading bacterium isolated from a deep-sea hydrothermal vent. Mar Genomics 50:100697. https://doi.org/ 10.1016/j.margen.2019.100697

\section{Publisher's Note}

Springer Nature remains neutral with regard to jurisdictional claims in published maps and institutional affiliations.

Ready to submit your research? Choose BMC and benefit from:

- fast, convenient online submission

- thorough peer review by experienced researchers in your field

- rapid publication on acceptance

- support for research data, including large and complex data types

- gold Open Access which fosters wider collaboration and increased citations

- maximum visibility for your research: over $100 \mathrm{M}$ website views per year

At BMC, research is always in progress.

Learn more biomedcentral.com/submissions 